\title{
Distribution of HIV-1 subtypes circulating in Slovakia (2009-2012)
}

\author{
Z. CHABADOVÁ ${ }^{1}$, M. HABEKOVÁ ${ }^{1}$, P. TRUSKA ${ }^{2}$, T. DROBKOVÁ ${ }^{1}$, M. MOJZESOVÁ ${ }^{1}$, D. STANEKOVÁ ${ }^{1}$
}

\author{
${ }^{1}$ National Reference Center for HIV/AIDS Prevention, Slovak Medical University, Limbová 14, 83103 Bratislava, Slovak Republic; \\ ${ }^{2}$ Institute of Public Health of the Capital of Slovakia, 82009 Bratislava, Slovak Republic
}

Received May 16, 2014; accepted November 3, 2014

\begin{abstract}
Summary. - Slovakia is one of the European countries reporting a low prevalence of human immunodeficiency virus 1 (HIV-1) infection. The HIV-1 subtype B was previously the most prevalent in Slovakia and mostly associated with men having sex with men (MSM) (Habekova et al., 2010). The aim of this study was to determine the distribution of individual HIV-1 subtypes among the virus-positive individuals diagnosed in 2009-2012 in Slovakia and to compare these data with those from 2004-2008. The HIV-1 subtype B exhibited the highest prevalence $(86.1 \%)$ and was mostly associated with MSM as stated before. HIV-1 non-B subtypes were found in $13.9 \%$ of patients, led by CRF01_AE (6.3\%) and followed by subtype C (2.8\%), F1 (1.4\%), CRF03_AB (1.4\%), G (0.7\%), CRF02_AG (0.7\%), and CRF12_BF (0.7\%). The incidence of non-B subtypes varied in 2009-2012, showing a maximum in 2012. MSM represented the main risk group for total HIV-1 (68.1\%) as well as B subtype (63.9\%) infections in Slovakia. In contrast, the heterosexual contact represented the main route of HIV-1 acquisition of the non-B subtype virus infection. Together with the increase in the number of patients infected with the viruses of non-B subtype also other changes were observed: infections with the viruses of non-B subtype became more common among MSM and not so strongly associated with heterosexual contact. All these findings may help to design the right strategy for retaining of HIV epidemic in Slovakia at low level.
\end{abstract}

Keywords: HIV-1; B subtype; non-B subtypes; Slovakia

\section{Introduction}

HIV infection represents a global health problem. By the end of 2012 UNAIDS estimated that 35.3 million people were infected by HIV and 2.3 million people had only been infected during that year (UNAIDS, 2013). An extensive genetic diversity and rapid evolution are the main characteristics of HIV-1 which contribute to unsuccessful fight with HIV/AIDS. Factors such as high rate of recombinations caused by reverse transcriptase enzyme (Ramirez et al., 2008), which lacks a proof-reading mechanism (Roberts et al., 1988), together with high replication rate (Ho et al., 1995),

E-mail: zuzana.chabadova@szu.sk; phone: +421-259-370-144. Abbreviations: $\mathrm{CRF}=$ circulating recombinant form; IVDU $=$ intravenous drug user; HIV-1 = human immunodeficiency virus 1; $\mathrm{MSM}=$ men having sex with men; $\mathrm{PRO}=$ protease; $\mathrm{RT}=$ reverse transcriptase; SIV = Simian immunodeficiency virus are responsible for genetic variability of HIV-1 (Hemelaar et al., 2012). Insertions, deletions, and duplications contribute to the genetic heterogeneity of HIV-1 (Hu and Temin, 1990) and, moreover, they result in the generation of genetically diverse viral populations differing by up to $10 \%$ within each infected individual (Korber et al., 2001).

On the basis of phylogenetic analysis of numerous isolates obtained from diverse geographic origins, HIV-1 is divided into four groups: $\mathrm{M}$ (main), $\mathrm{O}$ (outlier), $\mathrm{N}$ (non- $\mathrm{M}$, non-O) and $\mathrm{P}$ group. The groups represent four separated introductions into the human population by independent cross-species transmissions of SIV in West and Central Africa (Roques et al., 2004; Van Heuverswyn et al., 2006; Plantier et al., 2009; Vallari et al., 2011). Within HIV-1 group M, which accounts for the majority of infections worldwide, most sequences fall into a limited number of phylogenetically associated groups, allowing the classification of $\mathrm{HIV}-1$ group $\mathrm{M}$ into the clades called subtypes (A-D, F-H, J-K) and sub-subtypes (A1-A4, F1, F2). 58 CRFs (circulating recombinant forms) and some 
URFs (unique recombinant forms) had been described by December 2013 (Brun-Vezinet and Charpentier, 2013; HIV and SIV Nomenclature).

Hemelaar et al. (2011) published results of the global and regional distributions of HIV-1 subtypes and CRFs in 2011 worldwide. HIV-1 subtype $\mathrm{C}$ was determined as the most prevalent genetic form globally and was responsible for nearly half (48\%) of all global infections. Viruses of subtype A were accounted for $12 \%$ of HIV-1 infections, followed by viruses of subtype B (11\%), CFR02_AG (8\%), CRF01_AE (5\%), subtype $\mathrm{G}(5 \%)$ and subtype D (2\%). HIV-1 subtypes $\mathrm{F}, \mathrm{H}, \mathrm{J}$ and $\mathrm{K}$ caused less than $1 \%$ of infections worldwide (Hemelaar et al., 2011).

In Europe, HIV-1 subtype B is the most common (66.1\%) one. It is spread mostly among MSM, whilst strains of non-B subtypes are often associated with heterosexual transmission or immigration representing following prevalence: subtype A1 (6.9\%), subtype C (6.8\%), CRF02_AG (4.7\%) and CRF01_AE (4.0\%) (Paraschiv et al., 2012; Abecasis et al., 2013). HIV-1 subtype B prevails also in countries bordering Slovakia: Austria, Czech Republic, Hungary and Poland (Falkensammer et al., 2007; Linka et al., 2008; Mezei et al., 2000, 2011; Stanczak et al., 2010). Ukraine as the former USSR country is characterized by the high prevalence of subtype A and the second most common B subtype (Saad et al., 2006; Bobkova et al., 2013). Slovakia belongs to the European countries characterized by a low prevalence of HIV-1 infection although there is an evidence of increasing transmission, especially through sexual contact between men (ECDC, 2013). Subtype B was determined as the most prevalent genetic form in Slovakia (Mayer et al., 1998; Habekova et al., 2010).

The aim of this study was ( $i$ ) to determine the current prevalence of HIV-1 B and non-B subtypes in Slovakia in 2009-2012, (ii) to characterize the HIV-1 patients demographically and regarding the route of their infection, (iii) to characterize the HIV-1 B and non-B subtype isolates phylogenetically on the basis of their RT and PRO sequences, and (iv) to make all possible comparisons with corresponding data for the previous period (2004-2008).

\section{Materials and Methods}

Patients. $144 \mathrm{HIV}-1$ positive patients were enrolled in this study. All patients were antiretroviral therapy naïve and newly diagnosed in the National Reference Center for HIV/AIDS Prevention in Bratislava, Slovakia. Plasma samples were collected up to 6 months after HIV-1 diagnosis between 2009 and 2012 for routine genotyping and drug resistance testing. Personal data concerning the route of transmission, country of origin and presumed country of HIV-1 acquisition were collected from patients during a pre-test or posttest counseling. Distribution of HIV-1 B and non-B subtypes was analyzed in the relationship to personal data.
Nested RT-PCR. HIV-1 RNA isolation from plasma samples was accomplished using NucleoSpin ${ }^{\circledR}$ RNA virus isolation kit (Macherey-Nagel, Germany). The nested RT-PCR and sequencing of HIV pol region was carried out with the use of in-house procedures according to ANRS1 protocol for RT and PRO (ANRS AC11 Resistance Study Group, 2008).

Sequencing and phylogenetic analysis. All $144 \mathrm{HIV}-1$ pol sequences were firstly analyzed by REGA HIV-1 Subtyping Tool (REGA HIV-1 Subtyping Tool) to obtain preliminary HIV-1 subtype classification. Nucleotide alignments were prepared by comparing a set of consensus sequences of HIV-1 group M clades (including subtypes, subsubtypes and CRFs) that are available in Los Alamos HIV Databases (Los Alamos HIV Sequence Database) using CLUSTAL W software (Labarga et al., 2007), MEGA version 6.0 (Tamura et al., 2013) and BioEdit software packages (Hall, 1999). Firstly, the 480 bp alignment of RT sequences was prepared and alternatively in 16 cases, the 387 bp alignment of PRO sequences was used for HIV subtyping. Molecular phylogenetic analysis was performed using ML (maximum likelihood) method implemented in MEGA version 6.0 software (Tamura et al., 2013), using HKY (Hasegawa-Kishino-Yano) model as nucleotide substitution model and gamma distribution of rate variability among sites, calculated from the data with three discrete gamma categories. The bootstrap values (bootstrapping with 1000 replicates) above $60 \%$ were considered significant and shown at tree nodes. Initial trees for the heuristic search were made automatically and were obtained by applying the $\mathrm{NJ}$ (neighbor-joining) method to a matrix of pair wise distances estimated using MCL (maximum composite likelihood) approach. The sequences described in this article have been deposited in the GenBank Nucleotide Sequence Database under Acc. Nos. KJ483816 - KJ483943 and KJ483944 - KJ483959.

\section{Results and Discussion}

\section{Study population}

Demographic characteristics of the study population are illustrated in Table 1. The majority of all studied patients were men $(93.1 \%)$. The mean age of the patients was 32.0 years (10-62 years), for men and women 32.9 (19-62 years) and 27.0 years (10-51 years), respectively. The youngest individual was 10 and the oldest was 62 at the time of HIV diagnosis. Most of the patients were infected by sexual contact between men (68.1\%), followed by patients infected by unprotected heterosexual contact and intravenous drug use. Similar results were obtained in 2004-2008 when more than half of HIV-1 infected patients were MSM (Habekova et al., 2010).

\section{HIV-1 B subtype}

The two phylogenetic trees (Fig. 1 and 2) were constructed from HIV-1 pol sequences that cluster with the consensus 
Table 1. Demographic characteristics of HIV-1 patients in Slovakia in 2009-2012 and routes of the virus acquisition

\begin{tabular}{|c|c|c|c|c|}
\hline \multirow{5}{*}{ HIV-1 patients } & & \multicolumn{3}{|c|}{ Number (\%) } \\
\hline & & Total & B subtype & Non-B subtype \\
\hline & Total & $144(100.0 \%)$ & $124(86.1 \%)$ & $20(13.9 \%)$ \\
\hline & Females & $10(6.9 \%)$ & $4(2.8 \%)$ & $6(4.2 \%)$ \\
\hline & Males & $134(93.1 \%)$ & $120(83.3 \%)$ & $14(9.7 \%)$ \\
\hline \multirow{4}{*}{ Route of the virus acquisition } & Heterosexual contact & $28(19.4 \%)$ & $20(13.9 \%)$ & $8(5.6 \%)$ \\
\hline & IVDU & $3(2.1 \%)$ & $2(1.4 \%)$ & $1(0.7 \%)$ \\
\hline & MSM & $98(68.1 \%)$ & $92(63.9 \%)$ & $6(4.2 \%)$ \\
\hline & Unknown & $15(10.4 \%)$ & $10(6.9 \%)$ & $5(3.5 \%)$ \\
\hline \multirow{2}{*}{ Patients' country of origin } & Slovakia & $130(90.3 \%)$ & $119(82.6 \%)$ & $11(7.6 \%)$ \\
\hline & Outland & $14(9.7 \%)$ & $5(3.5 \%)$ & $9(6.3 \%)$ \\
\hline \multirow{4}{*}{$\begin{array}{l}\text { Presumed country of the virus } \\
\text { acquisition }\end{array}$} & Slovakia & $61(42.4 \%)$ & $55(38.2 \%)$ & $6(4.2 \%)$ \\
\hline & Outland & $33(22.9 \%)$ & $27(18.8 \%)$ & $6(4.2 \%)$ \\
\hline & Non-european outland & $13(9.0 \%)$ & $7(4.9 \%)$ & $6(4.2 \%)$ \\
\hline & Unknown & $37(25.7 \%)$ & $35(24.3 \%)$ & $2(1.4 \%)$ \\
\hline
\end{tabular}

of HIV-1 B subtype. The analysis showed that 124 of all 144 (86.1\%) sequences were derived from patients infected with HIV-1 subtype B viruses. HIV-1 B subtype remained the most prevalent genetic form in Slovakia in 2009-2012 like in the previous period (2004-2008) (Habekova et al., 2010). These findings are consistent with data coming from Europe, reporting the highest prevalence of HIV-1 B subtype (Paraskevis et al., 2009). Moreover, regarding the data of route of transmission in Europe, being infected with a subtype B virus was more common among MSM than among patients in other transmission groups (Vercauteren et al., 2009; Chalmet et al., 2010; Abecasis et al., 2013; Frentz et al., 2013). According to our results, MSM still remained associated with $68.1 \%$ of all HIV-1 infections (98 of 144) in Slovakia and with $74.2 \%$ of HIV-1 subtype B infections (92 of 124). As compared to 2004-2008, prevalence of HIV-1 subtype B (66.4\%) became increasing among MSM in Slovakia (Habekova et al., 2010). The highest prevalence of subtype B among MSM is related to the high number of men infected with subtype B strains which was showed in Slovakia by our study and by other studies from Europe (Abecasis et al., 2013).

Regarding the origin of subtype B strains, the majority $(89.8 \%)$ of them circulates in European countries (Frentz et al., 2013). Data of our study revealed that at least $57.0 \%$ of all patients were infected with subtype B viruses that were already found in other persons in Europe before (38.2\% in Slovakia, $18.8 \%$ in other European countries). In relation to the high proportion of patients with unknown origin of subtype B strains the resulting number could be even higher.

According to literature, the HIV-1 epidemic is mainly driven within country transmission (Kouyos et al., 2010; Frentz et al., 2013). Our data indicate that it is at least 38.2\% of HIV-1 B subtype infections having Slovak origin in Slovakia and this number could be higher. On the other hand, significant number $(23.7 \%)$ of HIV-1 infections originating from outland (18.8\% from other European countries, $4.9 \%$ from non-European outland) suggests that many HIV-1 strains were introduced into the Slovak population.

\section{HIV-1 non-B subtypes}

Based on the phylogenetic analysis (Fig. 3), 20 of all 144 HIV-1 pol sequences were classified into the HIV-1 non-B clades, which represent the prevalence of $13.9 \%$. 7 strains were pure subtypes $(\mathrm{C}, \mathrm{F} 1, \mathrm{G})$ and 13 strains clustered with the consensuses of different CRFs (CRF01_AE, CRF02_AG, CRF03_AB, CRF12_BF). The CRF01_AE was the most prevalent $(6.3 \%)$ among non-B subtypes, followed by subtype C (2.8\%), F1 (1.4\%), CRF03_AB (1.4\%), G (0.7\%), CRF02_AG (0.7\%) and CRF12_BF (0.7\%). As compared to the period of 2004-2008, prevalence of non-B subtypes increased almost twice (Habekova et al., 2010). These findings correspond with results published by Paraskevis et al. that showed an increasing prevalence of HIV-1 non-B subtypes in Europe (Paraskevis et al., 2009).

Moreover, distribution of non-B subtypes varied in 2009-2012 as follows: $7.7 \%$ in $2009,14.8 \%$ in $2010,10.0 \%$ in 2011 and $23.7 \%$ in 2012 (Fig. 4). A significant increase was recorded in 2012 when 9 of all 20 patients infected with HIV-1 non-B viruses were diagnosed (Table 2). These data suggest that HIV-1 epidemic in Slovakia became more variable. This reality could be the consequence of travel and migration that play a key role in the early spread of HIV due to easier international traveling within Europe (Frentz et al., 2013).

Regarding the route of transmission, heterosexual contact was the most common among patients infected with non-B strains, as it was found in 2004-2008 in Slovakia (Habekova 


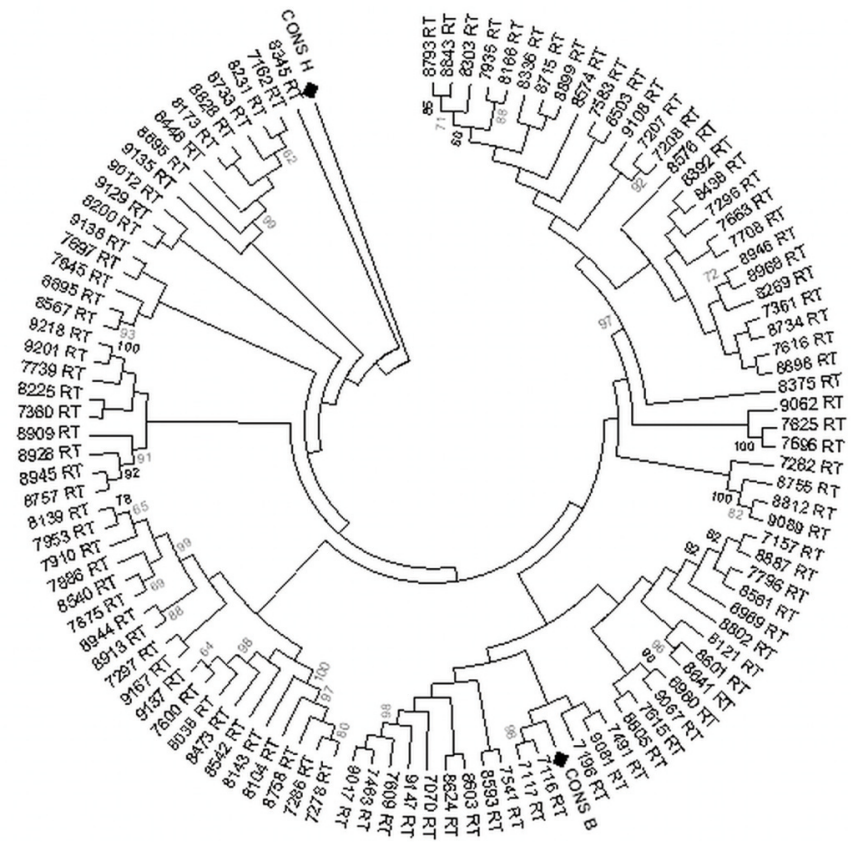

Fig. 1

RT region-based phylogenetic tree of HIV-1 subtype B isolates The tree was constructed using the ML method based on the HKY model. The subtype $\mathrm{H}$ served as outgroup. Subtype B and H consensus sequences (full squares) are included.

et al., 2010) and also in Europe (Abecasis et al., 2013; Frentz et al., 2013). On the other hand, the number of patients with non-B strains infected by sexual contact between men had increased from $0.7 \%$ in 2004-2008 (Habekova et al., 2010 ) to $4.2 \%$ in $2009-2012$. Generally, the proportion of men infected with non-B subtype viruses increased from $3.5 \%$ (5 men) (Habekova et al., 2010) to $9.7 \%$ (14 men) in this study.

The phylogenetic analysis of non-B sequences revealed some clusters that could indicate transmission events between particular patients. Based on post-test evaluation it was confirmed that patients coded 8491 and 8568 harboring subtype $\mathrm{C}$ strain were sexual partners. This was proved also by the phylogenetic tree and the bootstrap value showing $100 \%$.

9 of all 20 non-B strains clustered with the consensus CRF01_AE. According to patients' data, two strains of the cluster were obtained from a homosexual pair (coded 9092, 9122) which was consistent with the bootstrap value $100 \%$. Other three patients with the CRF01_AE strains were infected through heterosexual contact and for the rest four patients the route of HIV-1 transmission remained unknown. In comparison with the previous period 2004-2008 (Habekova et al., 2010), significant increase of CRF01_AE distribution was observed in 2009-2012. Moreover in 2012, 6 persons infected

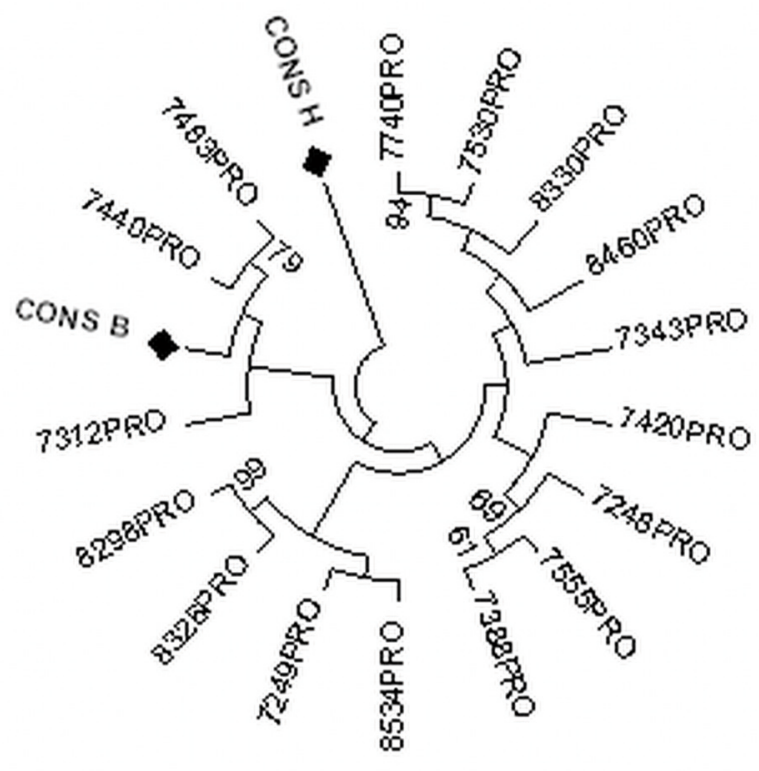

Fig. 2

PRO region-based phylogenetic tree of HIV-1 subtype B isolates The tree was constructed using the ML method based on the HKY model. The subtype $\mathrm{H}$ served as outgroup. Subtype B and $\mathrm{H}$ consensus sequences (full squares) are included.

with CRF01_AE strains were diagnosed and only three of them have an origin of HIV-1 infection in Slovakia. Despite the fact, no epidemiological association was proved among CRF01_AE infected patients, with an exception of the pair of MSM coded 9092 and 9122. Other two strains of CRF03_AB clustered together and have a common origin in Ukraine. The strains were derived from a heterosexual pair (coded $7509,7907)$ which could be suggested by the similarity in the bootstrap analysis. According to literature, this newly identified variant CRF03_AB circulates in 1.3\% in Ukraine (Los Alamos HIV Sequence Database/Geography).

Regarding the origin of HIV-1 non-B viruses in Europe, patients infected with these strains often came from Sub-Saharan countries (31.7\%) (Chalmet et al., 2013). In Slovakia, 4 of all 20 non-B infected patients (coded 7062, $7846,8710,8911$ ) have probable origin of HIV-1 infection in Africa which represents $20 \%$ of all non-B infections. The strain from patient coded 7062 clustered with subtype $G$ and originates from Nigeria where the HIV-1 subtype G circulates frequently (39.8\%) (Los Alamos HIV Sequence Database/Geography). The patients coded 7846 and 8911 were infected with two African strains probably by contact with their sexual partners originating from Africa. The patient coded 7846 was infected by CRF02_AG strain originating from Cameroon where prevalence of the CRF is 39.7\% (Los 
Alamos HIV Sequence Database/Geography). The second strain coded 8911 clustered with HIV-1 subtype C occurring in Africa very frequently (Los Alamos HIV Sequence Database/Geography). The strain coded 8710 also clustered with the subtype $\mathrm{C}$ consensus and comes from South Africa.

In Europe, many of patients with HIV-1 non-B strains became infected likely before they moved to Europe (Frentz et al., 2013). When comparing our data with those from Europe, an equivalent situation could be applicable for Slovakia. 6 of 20 patients with HIV-1 non-B viruses (coded 7062, 8710, $7869,7907,8467,8982)$ declared that they acquired their infection in the country from which they originate. As shown, viruses of the patients coded 7062 and 8710 came to Slovakia from Africa, patient coded 7869 was from Georgia, and the patient coded 7907 from Ukraine. The CRF01_AE strains coded 8467 (from Czech Republic) and 8982 (from Vietnam) came from the countries in which they also occur (Los Alamos HIV Sequence Database/Geography). Except these already mentioned cases, there are other 6 non-B strains coming from outland (codes 7509, 7695, 7846, 8911, 9013, 9251). The CRF03_AB strain coded 7509 probably originates in Ukraine because of the possible HIV-1 transmission from the partner coded 7907. The strain CRF01_AE coded 9013 should originate from Hungary according to known epidemiological data but no previous occurrence of the CRF was recorded in that country (Los Alamos HIV Sequence Database/Geography). A homosexual man (coded 9251) was infected with CRF12_BF strain in Austria where an occurrence of the CRF is very rare (Los Alamos HIV Sequence Database/Geography). When taking to account the origin of these mentioned strains, 12 of all 20 patients infected with HIV-1 non-B subtype strains came from outland and their origin is not associated with any other Slovak HIV-1 non-B strains. On the other hand, there were strains of the three HIV-1 non-B subtypes presumed to have an origin in Slovakia: F1 (patient coded 7150), C (patients coded 8491, 8568) and CRF01_AE (patients coded 8930, 9092, 9122). All the three subtypes have already circulated in Slovakia (Habekova et al., 2010). Based on these findings it was shown that the epidemic of HIV-1 non-B subtypes became a combined result of both migration and domestic transmission. Similar situation was observed in Switzerland where only $<25 \%$ of all non-B infections diagnosed could be prevented by domestic interventions (Von Wyl et al., 2011). Therefore as in Switzerland as well as in Slovakia, awareness should be raised among immigrants and individuals with partners from high prevalence countries to restrain the spread of non-B subtypes (Kouyous et al., 2010; Von Wyl et al., 2011).

In conclusion, the study described the prevalence of HIV-1 B and non-B subtypes in Slovakia in 2009-2012. Our findings confirmed the fact that distribution of HIV-1 varied in this period, showing a maximum in the year 2012. Sexual contact between men remained the main risk factor

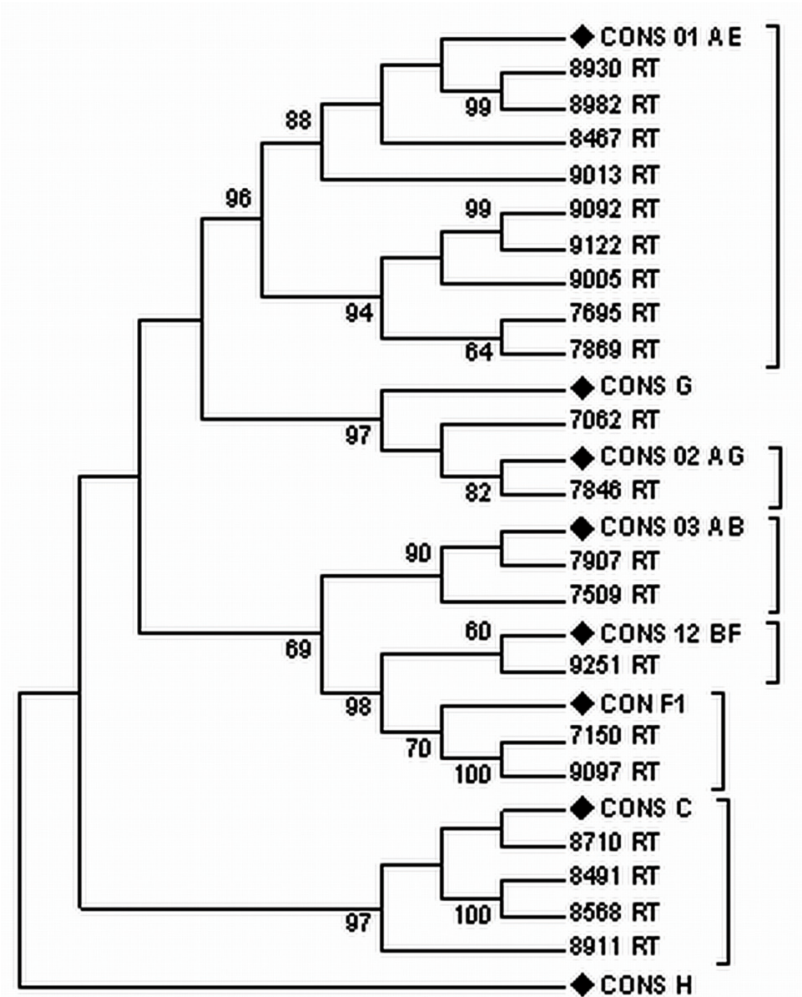

Fig. 3

RT region-based phylogenetic tree of HIV-1 non-B subtype isolates The tree was constructed using the ML method based on the HKY model. The subtype $\mathrm{H}$ served as outgroup. Consensus sequences of subtype C, F1, $\mathrm{G}, \mathrm{H}, \mathrm{CRF} 01 \_\mathrm{AE}, \mathrm{CRF} 02 \_\mathrm{AG}, \mathrm{CRF} 03 \_\mathrm{AB}$ and CRF12_BF (full squares) are included.

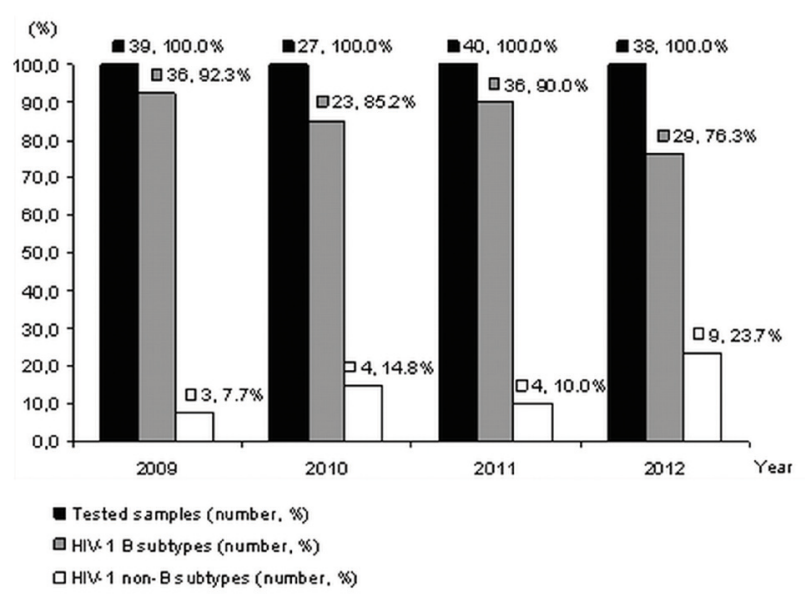

Fig. 4

Prevalence of HIV-1 isolates of subtypes B and non-B in Slovakia in 2009-2012 
Table 2. Epidemiological data of patients infected with HIV-1 non-B viruses

\begin{tabular}{|c|c|c|c|c|c|c|}
\hline \multicolumn{2}{|c|}{ Patients } & \multicolumn{5}{|c|}{ HIV-1 infection } \\
\hline Code & Sex & Country of origin & Virus subtype & Route of infection & $\begin{array}{l}\text { Presumed country } \\
\text { of virus acquisition }\end{array}$ & $\begin{array}{c}\text { Year of } \\
\text { diagnosis }\end{array}$ \\
\hline 8491 & $\mathrm{M}$ & Slovakia & $\mathrm{C}$ & MSM & Slovakia & 2011 \\
\hline 8568 & M & Slovakia & $\mathrm{C}$ & MSM & Slovakia & 2011 \\
\hline 8710 & M & South Africa & $\mathrm{C}$ & Not known & South Africa & 2011 \\
\hline 8911 & $\mathrm{~F}$ & Slovakia & $\mathrm{C}$ & Heterosexual & Africa (?) & 2012 \\
\hline 7150 & M & Slovakia & $\mathrm{F} 1$ & IVDU & Slovakia & 2009 \\
\hline 9097 & M & Slovakia & F1 & MSM & Not known & 2012 \\
\hline 7062 & M & Nigeria & G & Heterosexual & Nigeria & 2009 \\
\hline 7695 & $\mathrm{~F}$ & Ukraine & CRF01_AE & Heterosexual & Ukraine & 2010 \\
\hline 7869 & M & Georgia & CRF01_AE & Not known & Georgia & 2010 \\
\hline 8467 & M & Czech Republic & CRF01_AE & Heterosexual & Czech Republic & 2011 \\
\hline 8930 & $\mathrm{~F}$ & Slovakia & CRF01_AE & Heterosexual & Slovakia & 2012 \\
\hline 8982 & $\mathrm{~F}$ & Vietnam & CRF01_AE & Not known & Vietnam & 2012 \\
\hline 9005 & M & Russia & CRF01_AE & Not known & Not known & 2012 \\
\hline 9013 & M & Slovakia & CRF01_AE & Not known & Hungary & 2012 \\
\hline 9092 & M & Slovakia & CRF01_AE & MSM & Slovakia & 2012 \\
\hline 9122 & M & Latvia & CRF01_AE & MSM & Slovakia & 2012 \\
\hline 7846 & $\mathrm{~F}$ & Slovakia & CRF02_AG & Heterosexual & Cameroon & 2010 \\
\hline 7509 & $\mathrm{~F}$ & Slovakia & CRF03_AB & Heterosexual & Ukraine & 2009 \\
\hline 7907 & M & Ukraine & CRF03_AB & Heterosexual & Ukraine & 2010 \\
\hline 9251 & M & Slovakia & CRF12_BF & MSM & Austria & 2012 \\
\hline
\end{tabular}

of HIV-1 infection associated mostly with HIV-1 B subtype infection. Our findings are consistent with results of the last $2^{\text {nd }}$ generation surveillance provided in MSM in Slovakia, in which $6.1 \%$ prevalence of HIV-1 infections was described among MSM (Mirandola et al., 2009). Moreover, results of our study revealed multiple introductions of HIV-1 viruses into the Slovak population. All obtained data and findings could help to design the targeted prevention in high risk MSM group in Slovakia and focus on retaining HIV prevalence at low level in Slovakia.

Acknowledgements. This work was in part supported by the grant No. LSHP-CT-2006-518211 (project Europe HIV Resistance) from the EU commission and by the realization of the project "Center of excellence of environmental health", ITMS No. 26240120033, based on the supporting operational Research and development program financed from the European Regional Development Fund.

\section{References}

Abecasis AB, Wensing AM, Paraskevis D, Vercauteren J, Theys K, Van de Vijver DA, Albert J, Asjo B, Balotta C, Beshkov D, Camacho, RJ, Clotet B, De Gascun C, Griskevicius A, Grossman Z, Hamouda O, Horban A, Kolupajeva T, Korn K, Kostrikis LG, Kucherer C, Liitsola K, Linka M, Nielsen C, Otelea D, Paredes R, Poljak M, Puchhammer-Stockl E, Schmit JC, Sonnerborg A, Stanekova D, Stanojevic M,
Struck D, Boucher CA, Vandamme AM (2013): HIV-1 subtype distribution and its demographic determinants in newly diagnosed patients in Europe suggest highly compartmentalized epidemics. Retrovirology 10. http:// www.retrovirology.com/content/pdf/1742-4690-10-7.pdf http://dx.doi.org/10.1186/1742-4690-10-7

ANRS AC11 Resistance Study Group (2008): PCR and sequencing procedures: HIV-1. http://www.hivfrenchresistance.org/ ANRS-procedures.pdf

Bobkova M (2013): Current status of HIV-1 diversity and drug resistance monitoring in the former USSR. AIDS Rev. 15, 204-212. http://www.aidsreviews.com/ files/2013_15_4_204-212.pdf

Brun-Vezinet F, Charpentier C (2013): Update on the human immunodeficiency virus. Med. Mal. Infect. 43,177-184. http://dx.doi.org/10.1016/j.medmal.2013.03.001

Chalmet K, Staelens D, Blot S, Dinakis S, Pelgrom J, Plum J, Vogelaers D, Vandekerckhove L, Verhofstede C (2010): Epidemiological study of phylogenetic transmission clusters in a local HIV-1 epidemic revelas distinct differences between subtype $B$ and non-B infections. BMC Infect. Dis. 10. http://www.biomedcentral.com/1471-2334/10/262 http://dx.doi.org/10.1186/1471-2334-10-262

ECDC (2013): HIV/AIDS surveillance in Europe 2012. http://www. ecdc.europa.eu/en/publications/Publications/hiv-aidssurveillance-report-2012-20131127.pdf

Falkensammer B, Doerler M, Kessler HH, Puchhammer-Stoeckl E, Parson W, Duftner C, Dietrich MP, Stoiber H (2007): Subtype and genotypic resistance analysis of HIV-1 infected patients in Austria. Wien. Klin. Wochenschr. 119,181-185. 
http://link.springer.com/article/10.1007\%2Fs00508-006 -0745-4\#page-1 http://dx.doi.org/10.1007/s00508-006$\underline{0745-4}$

Frentz D, Wensing AM, Albert J, Paraskevis D, Abecasis AB, Hamouda O, Jorgensen LB, Kucherer C, Struck D, Schmit JC, Asjo B, Balotta C, Beshkov D, Camacho RJ, Clotet B, Coughlan S, De Wit S, Griskevicius A, Grossman Z, Horban A, Kolupajeva T, Korn K, Kostrikis LG, Liitsola K, Linka M, Nielsen C, Otelea D, Paredes R, Poljak M, Puchhammer-Stockl E, Sonnerborg A, Stanekova D, Stanojevic M, Vandamme AM, Boucher CA, Van de Vijver DA; SPREAD Programme (2013): Limited cross-border infections in patients newly diagnosed with HIV in Europe. Retrovirology 10. http:// www.retrovirology.com/content/pdf/1742-4690-10-36.pdf http://dx.doi.org/10.1186/1742-4690-10-36

Habekova M, Takacova M, Lysy J, Mokras M, Camacho R, Truska P, Stanekova D (2010): Genetic subtypes of HIV type 1 circulating in Slovakia. AIDS Res. Hum. Retroviruses 26, 1103-1107. http://online.liebertpub.com/doi/ abs/10.1089/aid.2009.0220?journalCode=aid http:// dx.doi.org/10.1089/aid.2009.0220

Hall TA (1999): BioEdit: a user-friendly biological sequence alignment editor and analysis program for Windows 95/98/ NT. Nucl. Acids Symp. Ser. 41, 95-98. http://www.mbio. ncsu.edu/jwb/papers/1999Hall1.pdf

Hemelaar J, Gouws E, Ghys PD, Osmanov S, WHO-UNAIDS Network for HIV Isolation and Characterisation (2011): Global trends in molecular epidemiology of HIV-1 during 2000-2007. AIDS 25, 679-689. http://www.ncbi. nlm.nih.gov/pmc/articles/PMC3755761/ http://dx.doi. org/10.1097/QAD.0b013e328342ff93

Hemelaar J (2012): The origin and diversity of the HIV-1 pandemic. Trends Mol. Med. 18,182-192. http://www.sciencedirect. com/science/article/pii/S1471491411002103 http:// dx.doi.org/10.1016/j.molmed.2011.12.001

Ho DD, Neumann AU, Perelson AS, Chen W, Leonard JM, Markowitz M (1995): Rapid turnover of plasma virions and CD4 lymphocytes in HIV-1 infection. Nature 373,123-126. http://hebb.mit.edu/courses/9.53/art2.pdf http://dx.doi. org/10.1038/373123a0

Hu WS, Temin HM (1990): Retroviral recombination and reverse transcription. Science 250,1227-1233. http://dx.doi. org/10.1126/science. 1700865

Korber B, Gaschen B, Yusim K, Thakallapally R, Kesmir C, Detours V (2001): Evolutionary and immunological implications of contemporary HIV-1 variation. Br. Med. Bull. 58, 19-42. http://bmb.oxfordjournals.org/content/58/1/19. full http://dx.doi.org/10.1093/bmb/58.1.19

Kouyos RD, von Wyl V, Yerly S, Boni J, Taffe P, Shah C, Burgisser P, Klimkait T, Weber R, Hirschel B, Cavassini M, Furrer H, Battegay M, Vernazza PL, Bernasconi E, Rickenbach M, Ledergerber B, Bonhoeffer S, Gunthard HF (2010): Molecular epidemiology reveals long-term changes in HIV type 1 subtype B transmission in Switzerland. J. Infect. Dis. 201, 1488-1497. http://jid.oxfordjournals.org/content/201/10/1488.full http://dx.doi. org/10.1086/651951
Labarga A, Valentin F, Anderson M, Lopez R (2007): Web services at the European bioinformatics institute. Nucleic Acids Res. Web Services Issue. 35. http://www.ncbi.nlm.nih. gov/pmc/articles/PMC1933145/

Linka M, Bruckova M, Maly M, Vandasova J, Stankova, Reinis M (2008): A study of HIV-1 genetic diversity in the Czech Republic: 1986-2007. Cent. Eur. J. Public Health 16, 175177. http://www.ncbi.nlm.nih.gov/pubmed/19256285

Los Alamos HIV Sequence Database/Geography. http://www.hiv. lanl.gov/components/sequence/HIV/geo/geo.comp

Mayer V, Apetrei C, Habekova M, Tchentsova N, Bruckova M, Klaskala W, Baum MK, Brun-Vezinet F, Simon F (1998): HIV-1 diversity in heterosexual population in Slovakia, Ukraine and the Czech Republic. AIDS 12, 1006-1008.

Mezei M, Balog K, Takacs M, Toth G, Gyuris A, Segesdi J, Bakos A, Vodros D, Banhegyi D, Berencsi G, Minarovits J (2000): Genetic subtypes of HIV type 1 in Hungary. AIDS Res. Hum. Retroviruses 16, 513-516. http://online.liebertpub. com/doi/abs/10.1089/088922200308927 http://dx.doi. org $/ 10.1089 / 088922200308927$

Mezei M, Ay E, Koroknai A, Toth R, Balazs A, Bakos A, Gyori Z, Banati F, Marschalko M, Karpati S, Minarovits J (2011): Molecular epidemiological analysis of env and pol sequences in newly diagnosed HIV type 1-infected, untreated patients in Hungary. AIDS Res. Hum. Retroviruses 27, 1243-1247. http://online.liebertpub.com/doi/ abs/10.1089/aid.2011.0077 http://dx.doi.org/10.1089/ aid.2011.0077

Mirandola M, Folch Toda C, Krampac I, Nita I, Stanekova D, Stehlikova D, Toskin I, Gios L, Foschia JP, Breveglieri M, Furegato M, Castellani E, Bonavina MG; SIALON network (2009): HIV bio-behavioural survey among men who have sex with men in Barcelona, Bratislava, Bucharest, Ljubljana, Prague and Verona, 2008-2009. Euro. Surveill. 14. http://www.eurosurveillance.org/ ViewArticle.aspx?ArticleId=19427

Paraschiv S, Otelea D, Batan I, Baicus C, Magiorkinis G, Paraskevis D (2012): Molecular typing of the recently expanding subtype B HIV-1 epidemic in Romania: evidence for local sperad among MSMs in Bucharest area. Infect. Genet. Evol. 12,1052-1057. http://www.sciencedirect.com/ science/article/pii/S1567134812000688 http://dx.doi. org/10.1016/j.meegid.2012.03.003

Paraskevis D, Pybus O, Magiorkinis G, Hatzakis A, Wensing AM, van de Vijver DA, Albert J, Angarano G, Asjo B, Balotta C, Boeri E, Camacho R, Chaix ML, Coughlan S, Costagliola D, De Luca A, de Mendoza C, Derdelinckx I, Grossman Z, Hamouda O, Hoepelman I, Horban A, Korn K, Kucherer C, Leitner T, Loveday C, Macrae E, Maljkovic-Berry I, Meyer L, Nielsen C, Op de Coul EL, Ormaasen V, Perrin L, Puchhammer-Stockl E, Ruiz L, Salminen MO, Schmit JC, Schuurman R, Soriano V, Stanczak J, Stanojevic M, Struck D, Van Laethem K, Violin M, Yerly S, Zazzi M, Boucher CA, Vandamme AM; SPREAD Programme (2009): Tracing the HIV-1 subtype B mobility in Europe: a phylogeographic approach. Retrovirology 6. http:// www.retrovirology.com/content/6/1/49/ http://dx.doi. org/10.1186/1742-4690-6-49 
Plantier JC, Leoz M, Dickerson JE, De Oliviera F, Cordonnier F, Lemee V, Damond F, Robertson, DL, Simon F (2009): A new human immunodeficiency virus derived from gorillas. Nat. Med. 15, 871-872. http://www.nature.com/ nm/journal/v15/n8/full/nm.2016.html http://dx.doi. org $/ 10.1038 / \mathrm{nm} .2016$

Ramirez BC, Simon-Loriere E, Galetto R, Negroni M (2008): Implications of recombination for HIV diversity. Virus Res. 134, 64-73. http://www.sciencedirect.com/science/article/ pii/S0168170208000270 http://dx.doi.org/10.1016/j. virusres.2008.01.007

REGA HIV-1 Subtyping Tool. www.hiv.lanl.gov

Roberts JD, Bebenek K, Kuntel TA (1988): The accuracy of reverse transcriptase from HIV-1. Science 242, 1171-1173. http:// www.sciencemag.org/content/242/4882/1171.long http:// dx.doi.org/10.1126/science. 2460925

Roques P, Robertson DL, Souquiere S, Apetrei C, Nerrienet E, Barre-Sinoussi F, Muller-Trutwin M, Simon F (2004): Phylogenetic characteristics of three new HIV-1 $\mathrm{N}$ strains and implications for the origin of group N. AIDS 18, 1371-1381. http://journals.lww.com/ aidsonline/Fulltext/2004/07020/Phylogenetic_characteristics_of_three_new_HIV_1_N.3.aspx http://dx.doi. org/10.1097/01.aids.0000125990.86904.28

Saad MD, Shcherbinskaya AM, Nadai Y, Kruglov YV, Antonenko SV, Lyullchuk MG, Kravchenko ON, Eerhart KC, Sanchez JL, Birx DL, Carr JK (2006): Molecular epidemiology of HIV type 1 in Ukraine: birthplace of an epidemic. AIDS Res. Hum. Retroviruses 22, 709-714. http://online.liebertpub.com/doi/abs/10.1089/aid.2006.22.709 http://dx.doi. org/10.1089/aid.2006.22.709

Stanczak GP, Stanczak JJ, Marczynska M, Firlag-Burkacka E, Wiercinska-Drapalo A, Leszczyszyn-Pynka M, Jablonowska E, Malolepsza E, Dyda T, Zabek P, Horban A (2010): Evolving patterns of HIV-1 transmitted drug resistance in Poland in the years 2000-2008. J. Med. Virol. 82, 1291-1294. http:// onlinelibrary.wiley.com/doi/10.1002/jmv.21782/d=1CAB2 D4475902601BCB078D7D575D64D.f02t02 http://dx.doi. org/10.1002/jmv.21782

Tamura K, Stecher G, Peterson D, Filipski A, Kumar S (2013): MEGA6: Molecular evolutionary genetics analysis version
6.0. Mol. Biol. Evol. 30, 2725-2729. http://mbe.oxfordjournals.org/content/early/2013/10/16/molbev.mst197 http://dx.doi.org/10.1093/molbev/mst197

UNAIDS (2013): UNAIDS report on the global AIDS epidemic 2013. http://www.unaids.org/en/media/unaids/contentassets/documents/epidemiology/2013/gr2013/UNAIDS_Global_Report_2013_en.pdf

Van Heuverswyn F, Li Y, Neel C, Bailes E, Keele BF, Liu W, Loul S, Butel C, Liegeois F, Bienvenue Y, Ngolle EM, Sharp, PM, Shaw GM, Daleporte E, Hahn BH, Peeters M (2006): Human immunodeficiency viruses: SIV infection in wild gorillas. Nature 444, 164. http://www.nature.com/nature/ journal/v444/n7116/full/444164a.html http://dx.doi. org $/ 10.1038 / 444164 a$

Vallari A, Holzmayer V, Harris B, Yamaguchi J, Ngansop C, Makamche F, Mbanya D, Kaptue L, Ndembi N, Gurtler L, Derave S, Brennan CA (2011): Confirmation of putative HIV-1 group in Cameroon. J. Virol. 85, 1403-1407. http://jvi.asm.org/content/85/3/1403.full http://dx.doi. org/10.1128/JVI.02005-10

Vercauteren J, Wensing AM, van de Vijver DA, Albert J, Balotta C, Hamouda O, Kucherer C, Struck D, Schmit JC, Asjo B, Bruckova M, Camacho RJ, Clotet B, Coughlan S, Grossman Z, Horban A, Korn K, Kostrikis L, Nielsen C, Paraskevis D, Poljak M, Puchhammer-Stockl E, Riva C, Ruiz L, Salminen M, Schuurman R, Sonnerborg A, Stanekova D, Stanojevic M, Vandamme AM, Boucher CA (2009). Transmission of drug-resistant HIV-1 is stabilizing in Europe. J. Infect. Dis. 200, 1503-1508. http://jid. oxfordjournals.org/content/200/10/1503.full.pdf http:// dx.doi.org/10.1086/644505

Von Wyl V, Kouyous RD, Yerly S, Boni J, Shah C, Burgisser P, Klimkait T, Weber R, Hirschel B, Cavassini M, Staehelin C, Battegay M, Vernazza PL, Bernasconi E, Ledergerber B, Bonhoeffer S, Gunthard HF; Swiss HIV Cohort Study (2011): The role of migration and domestic transmission in the spread of HIV-1 non-B subtypes in Switzerland. J. Infect. Dis. 204, 1095-1103. http://jid.oxfordjournals. org/content/204/7/1095.long http://dx.doi.org/10.1093/ infdis/jir491 